\title{
CHINESE FOREIGN DIRECT INVESTMENT IN BRAZIL: EVOLUTION, TRENDS AND CONCERNS OVER CRITICAL INFRASTRUCTURE
}

Gabriel de Barros Torres*

Pontificia Universidad Católica de Río de Janeiro

Recibido: 13 de diciembre de 2019 $\bowtie$ gabrielbt95@gmail.com Aceptado: 1 de marzo de 2020 DOI: $10.46553 /$ colec.31.1.2020.p17-36

Resumen: Como parte de la salida masiva de la inversión extranjera directa (IED) china observada en las últimas dos décadas, Brasil se ha convertido en uno de los principales receptores de IED china y una pieza central de las estrategias de seguridad alimentaria y energética del país asiático. Sin embargo, las adquisiciones en materia de infraestructura crítica y tecnologías sensibles por parte de las empresas estatales chinas han generado preocupación en todo el mundo sobre los posibles riesgos de seguridad nacional. En este contexto, este artículo tiene como objetivo (i) analizar la evolución de la IED china en Brasil desde 2010, identificando sus principales drivers y tendencias, y (ii) estudiar la tendencia mundial hacia el fortalecimiento de los mecanismos de detección de la IED, por razones de seguridad nacional: identificando sus implicaciones para la política de inversión de Brasil. En el contexto de la guerra comercial entre Estados Unidos y China y la rivalidad tecnológica, el principal argumento es que las medidas restrictivas sobre la IED, generalmente basadas en umbrales vagos y amplias definiciones de infraestructura crítica,

* El autor es Magíster en Análisis y Gestión de Políticas Internacionales por la Pontificia Universidad Católica de Río de Janeiro. Licenciado en Relaciones Internacionales por la misma institución, con énfasis en Comercio y Negocios Internacionales. Recientemente participó del Programa BRICS de la Universidad Fudan, investigando el Nuevo Banco de Desarrollo y la política económica de China. 
se han caracterizado por una confusión entre una evaluación realista del riesgo y los intereses geopolíticos en juego.

Palabras clave: IED, infraestructura crítica, tecnologías sensibles, proyección de inversiones, Brasil-China.

\begin{abstract}
As a part of the massive outflow of Chinese foreign direct investment observed in the past two decades, Brazil has emerged as a top recipient of Chinese FDI and central piece for China's food and energy security strategies. However, Chinese SOE's acquisitions of critical infrastructure and sensitive technologies have raised concerns worldwide over potential national security risks. In this context, this article aims to (i) analyze the evolution of Chinese FDI in Brazil since 2010, identifying its main drivers and trends, and to (ii) survey the global trend towards strengthening screening mechanisms for FDI, under national security grounds - identifying its implications for Brazil's investment policy. In the context of U.S.-China trade war and technological rivalry, it is argued that restrictive measures on FDI - generally based on vague thresholds and broad definitions of critical infrastructure - have been characterized by a blurring between realistic risk assessment and geopolitical interests.
\end{abstract}

Keywords: FDI; Critical infrastructure; Sensitive technologies; Investment screening; Brazil-China

\title{
I. Introduction
}

In 2016, Chinese outbound direct investment finally surpassed inward foreign direct investment, consolidating China as one of the top global investors overseas (Jaguaribe 2018). This massive capital outflow, largely associated to China's "going global" policy and, more recently, to the Belt and Road Initiative, has also reached Latin America. As the main recipient of Chinese investments in the region, Brazil has received over US\$ 58 billion in Chinese FDI in the past thirteen years (Cariello 2019a). During this period, investments from Chinese private and state-owned companies in Brazil underwent significant changes in their sectorial composition and 
degree of diversification, with an increasing emphasis on energy generation and transmission assets, as well as transport infrastructure projects.

However, the upsurge in Chinese global investments has raised concerns worldwide with acquisitions of so-called critical infrastructure and, more recently, sensitive technologies - allegedly threatening national security. The global trend towards strengthening screening mechanisms for FDI, most visible in developed economies in Europe and North America, is also affecting the developing world. In countries where Chinese FDI has traditionally focused on extractive industries and commodities, the increasing presence of Chinese SOEs in strategic sectors such as energy transmission and telecommunications has sparked debate on possible risks restrictive measures.

During the 1990s, understanding FDI as a positive engine for growth and development, most governments adopted liberal FDI regimes and facilitated investment through horizontal policies and bilateral agreements. Since then, a more nuanced view on FDI's contribution to long-term development and quality employment has emerged, weighing the impact of different modes of entry, types of company, and reinforcing the role of regulation (Velde 2006). In the current scenario, the emerging trend on FDI regulation and restriction has emphasized its impact on national security, particularly through foreign control of critical infrastructure, access to sensitive technologies and risk of surveillance and sabotage. However, in the context of the geopolitical rivalry between the U.S. and China - expressed in the trade war and its underlying technological drivers - realistic risk assessment for FDI has been increasingly blurred with geopolitical interests and pressures.

Accordingly, this essay is structured as follows: the next session outlines the main phases in the evolution Chinese foreign direct investment in Brazil since 2010 , followed by an analysis of its mode of entry and the dichotomy between mergers and acquisitions (brownfield) and greenfield investments. The subsequent section analyzes the global trend towards strengthening screening mechanisms for foreign direct investment under national security grounds, highlighting relevant cases and their underlying drivers. Finally, the implications of this trend for Brazilian investment policy are addressed, in light of the recent rise in anti-China rhetoric in Brazil and its pragmatic de-escalation. 


\section{Chinese Foreign Direct Investment in Brazil: Evolution and trends}

During the past decade, a major shift has taken place in the nature of Brazil-China economic relations: Although merchandise trade remains the leading bilateral flow - amounting to a record high of US\$ 98,6 billion in 2018 - Chinese foreign direct investment in Brazil has grown consistently since 2010. Between 2007 and 2018, the stock of confirmed Chinese investments in Brazil reached around US\$ 58 billion ${ }^{1}$, consolidating China as the 9th top global investor in Brazil ${ }^{2}$. From the Chinese perspective, Brazil represented the fourth top destination of foreign direct investment in the same period (Lins \& Ferreira 2019). Within Latin America, Brazil represents by far the main recipient of Chinese FDI, having absorbed 53\% of Chinese investments in the region between 2007 and 2018 (Cariello 2019a). Moreover, Chinese investments have been stimulated through innovative bilateral mechanisms, including the Brazil-China Fund, aimed at classifying priority infrastructure projects with partial resources from the China-LAC Industrial Cooperation Investment Fund (CLAIFUND).

Against the backdrop of Chinese expanding global investments in the past decades, the particular interest of Chinese companies in Brazil can be traced to two main factors: First, Brazil represents a key player in Chinese food and energy security strategies, supplying strategic commodities to the Chinese market: In 2018, Brazil accounted for $75 \%$ of Chinese total soy imports; $82 \%$ of Chinese total poultry imports and $9 \%$ of oil imports (Caramuru et al. 2019). As such, Chinese investments in Brazil are largely driven by an interest in accessing commodities, enhancing control over strategic supply chains and reducing costs of Chinese imports. It is noteworthy that Chinese central state-owned companies, which accounted

\footnotetext{
1 Precise data on Chinese foreign investments are hardly obtainable and depend on individual companies' confirmation and announcement. It is likely, thus, that volumes actually exceed this amount, considering unannounced investments and difficulties in tracing the original source of investments from "tax havens" such as Luxemburg and Hong Kong.

${ }^{2}$ Although Brazilian Central Bank ranks China as 9th top investor in 2018, data from the Brazilian Foreign Trade Chamber (CAMEX) places China as second top investor in Brazil in the same year. According to CAMEX, between 2010 and 2017, China alternated with the U.S. as first or second top investor in Brazil.
} 
for $82 \%$ of Chinese investments in Brazil in the past decade, ultimately respond to guidelines set by the SASAC - State-owned Assets Supervision and Administration Commission - ensuring the alignment of their activities to Chinese long-term priorities (Cariello 2019a).

Second, Chinese investments in Brazil are also driven by a marketoriented logic, with companies seeking profitable returns on investments at generally low risk. In this respect, the dimensions of the Brazilian domestic market and the lucrative opportunities observed in sectors such as energy and infrastructure have attracted a number of Chinese companies. In the energy sector, stable regulatory frameworks have been particularly attractive: The predictability associated to the recent definition and execution of multi-annual bidding calendars in the oil $\&$ gas and electric power sectors have generated multiple Chinese bidders, as similarly observed in infrastructure opportunities offered by the federal government's Investment Partnership Program (PPI) (Caramuru et al 2019).

Such motivations are not uncommon to Chinese investments elsewhere in Latin America, Africa and Southeast Asia, though in Brazil they have led to a particularly fast expansion since 2010. In only a decade of intense growth, Chinese investment has diversified into different sectors and evolved towards riskier operations - while preserving common characteristics throughout the period. Cariello (2019b) identifies four main stages in this process, each responding to different main drivers and with different implications for long-term national development:

Until mid-2010, Chinese FDI in Brazil was largely concentrated on the production of strategic commodities, especially soy, oil and iron ore. A key illustration of this phase is Sinopec's acquisition of $40 \%$ of Repsol Brazil's operations in 2010, for US\$ 7,1 billion - leading to a yet unsurpassed peak in Chinese FDI flows to Brazil, at US\$ 13,1 billion. Closely linked to Chinese food and energy security strategies, this phase emphasizes Chinese control over key stages of commodities' supply chains, ultimately exported to the Chinese market. However, as remarked by Velde (2006), this pattern of investment tends to offer limited contributions to recipient countries' long-term sustainable economic growth, by perpetuating dependency on low value-added commodities.

Between 2011 and 2013, Chinese FDI shifted focus to investments aimed at exploring the Brazilian domestic market, especially in the automotive and 
machinery sectors. Migrating from resource-seeking to market-seeking investments, this phase is illustrated by the entry of auto-maker Chery and construction equipment manufacturer Sany in Brazil. This period was also marked by the expansion of telecommunications and electronics companies such as Huawei and Lenovo in Brazil, driven by large consumer markets and overall high growth rates. Between 2013 and 2014, Chinese investments diversify towards financial services, with the entry in Brazil of major banks including the Industrial and Commercial Bank of China (ICBC). This movement aimed not only to support bilateral trade and investment operations, but also to underscore the gradual internationalization of the renminbi (CEBC 2016).

It is from mid-2014 onwards, though, that Chinese investments experience a new upsurge, now greatly focused on energy generation, transmission and distribution assets, led mostly by State Grid and China Three Gorges. In fact, it is estimated that the energy sector accounted for $76 \%$ of the total value of Chinese investments in Brazil between 2010 and 2016 (CEBC 2017). Among the most relevant operations during this new phase, an emblematic case was State Grid's winning bid for the construction and operation of two energy transmission lines from the Belo Monte Hydroelectric Dam to Brazil's Southeast region (Proença \& Kupfer 2018). It is noteworthy that, by applying ultra-high-voltage technology to its transmission lines, State Grid promotes energy efficiency and contributes to technological upgrading in Brazil - even though the company's acquisitions are in the center of recent accusations against Chinese alleged excessive control over critical infrastructure, as discussed in following sections.

More recently, the fourth and latest phase of Chinese investments in Brazil has also featured the participation of Chinese companies in concessions for transport infrastructure projects in Brazil - including the construction of major ports and railways in strategic regions, ultimately contributing to reduce high logistics costs in Brazilian trade. One example is China Communications Construction Company (CCCC)'s investment in a private use terminal in São Luís Port, directly related to facilitating soy and iron ore exports to China. In parallel to the increased emphasis on energy assets, China continues to invest significantly in agricultural tradings in order to control food production and commercialization: through the acquisition of Nidera and Noble Agri in 2014, China Oil and Food 
Corporation (COFCO) consolidated its influence as a key player in global food production (CEBC 2016).

It is noteworthy that, throughout the evolution of Chinese FDI in Brazil, a large proportion of investment operations in Brazil was carried by a small number of Chinese state-owned enterprises: Between 2010 and 2016, five Chinese companies accounted for $80 \%$ of the total value of Chinese investments in Brazil - Sinopec, State Grid, China Three Gorges, Sinochem and China Niobium (Kupfer \& Rocha 2018) ${ }^{3}$. Despite a recent trend of diversification towards new sectors and smaller private companies particularly in services - state-owned enterprise are expected to retain the bulk of Chinese investment in Brazil; one of the main reasons underlying growing concerns over critical infrastructure control, as discussed in following sections.

\section{Entry mode: brownfield vs. greenfield investments}

Despite the changing nature of Chinese investments in Brazil in the past decade, a common characteristic has remained unchanged through most of the period: Since 2010, mergers and acquisitions have represented the preferred modality for Chinese investments in Brazil, accounting for $81 \%$ of the value invested between 2010 and 2017 (Lins \& Ferreira 2019). By acquiring existing assets through M\&As, Chinese investors minimize risk and benefit from prior knowledge from local companies - facilitating access to local markets and assisting in understanding the particularities of Brazilian regulatory environment.

However, since 2017, this overall trend has been partially reversed, as the number of greenfield projects surpassed that of brownfield projects (M\&As) for the first time since 2014. In 2017, greenfield projects represented $49 \%$ of the total number of confirmed and announced Chinese investments in 2017 - against 32\% represented by M\&As and $19 \%$ by Joint Ventures (Cariello 2019a). In 2018, a similar distribution occurred, with

\footnotetext{
${ }^{3}$ While Sinopec and State Grid invested around US\$ 12 billion each between 2010 and 2016, CTG invested approximately US\$ 6,5 billion during the same period.
} 
greenfield projects accounting for 50\% of confirmed and announced Chinese investments (Cariello 2019b). However, when analyzing the value of confirmed investments, the preference for M\&As is reinforced, as they represented $69 \%$ of the total value invested by Chinese companies in $2017^{4}$. As such, it can be surmised that, despite the growing interest and announcements of greenfield projects in Brazil since 2017 - reflecting a greater maturity of Chinese investors in Brazil and domestic regulatory stability - confirmed investments are still dominated by mergers and acquisitions.

Differently from M\&As, greenfield projects tend to have a higher positive impact on local development, as they generate new jobs and develop local capabilities by establishing new operations and facilities, including factories and infrastructure projects. These investments also favor domestic capital formation and facilitate the transfer of more efficient technologies. As such, it has been empirically shown that greenfield investments have a substantially higher positive effect on long-term economic growth than M\&As (Harms \& Meón 2012). According to a report by the Atlantic Council, it is estimated that Chinese greenfield investments in Latin America amounted to US\$ 46 billion between 2003 and 2016, generating estimated 111,000 new jobs in the region. In the case of Brazil, Chinese greenfield investments amounted to US\$ 18 billion in the same period, generating around 38,200 new jobs. It is noteworthy that the majority of these new positions were created in the Brazilian manufacturing sector, as a reflection of Chinese market-seeking investments (Avendano et alt. 2017).

As Chinese investors become more mature and acquainted with the Brazilian market and regulatory framework, there is a great expectation among different stakeholders that greenfield investments will increase in the following years, particularly in transport infrastructure and logistics (Lins \& Fereira 2019). A persisting bottleneck for infrastructure investment in Brazil, however, relates to the quality of infrastructure projects - a

\footnotetext{
${ }^{4}$ According to data from the Brazilian Ministry of Economy, the proportion of M\&As in relation to the total value of Chinese confirmed annual investments is even higher, at $99 \%$ in 2017 and $93,5 \%$ in 2018 (SEAIN 2018).
} 
challenge common to many other G20 countries, featuring chronic deficits of bankable projects (CEBRI 2018).

\section{Critical Infrastructure and Sensitive Technologies: Restrictions on Foreign Direct Investment from China}

The upsurge in Chinese foreign direct investment in Brazil in the past decade is not an isolated case - in fact, Brazil represents a late-comer in the wave of rising Chinese global investments. Since before the formal launch of the Belt and Road Initiative, in 2013, Chinese outward direct investment experienced consistent growth in previous years, as a result of SOEs' internationalization under the "Going Global" policy. With the flexibilization of approval procedures for Chinese FDI, in 2014, Chinese non-financial investments abroad peaked at US\$ 170 billion in 2016. The new guidelines adopted that year by the NDRC, restricting FDI in sectors such as real estate and the entertainment industry, dropped FDI levels to US\$ 120 billion in the following year. Nonetheless, the rapid pace and magnitude of the expansion of Chinese global investments in the past decade is striking: Amounting to US\$ 73 billion in 2006, the stock of Chinese FDI in the world rose to US\$ 2 trillion in only thirteen years (Wachholz 2019), placing China as the second largest source of FDI in the world.

As Chinese investments expanded rapidly worldwide, governments have reacted differently: While many welcomed the upsurge as a contribution to address the massive global infrastructure gap, for example, others have regarded increased Chinese global presence with caution and suspicion. Especially among countries in which Chinese investments grew swiftly in large amounts, a common trend has been the strengthening of screening mechanisms for inward FDI, based on alleged national security risks. Implicitly or explicitly directed at China, these measures have prevented Chinese companies from investing in so-called critical infrastructure and sensitive technologies worldwide.

According to Esplugues (2018), the reasons behind the strengthening of screening mechanisms on FDI, on national security grounds, generally relate to three main potential security risks or threats: First, the risk of 
control by foreign companies of the supply of goods or services deemed crucial for the normal functioning of the host country, especially in sectors such as energy, telecommunications, transportation and health (critical infrastructure). By controlling strategic assets, foreign companies could ultimately disrupt, delay or impose conditions on the provision of these goods and services. A credible threat of dependency, however, must be connected with a limited number of close substitutes and high switching costs (Moran 2013).

Second, foreign direct investment might result in the acquisition of technologies ultimately harmful to the interests of recipient countries, especially connected to military technologies. In this respect, the assessment of threats depends on the broad availability of additional production and technical expertise globally, as well as the impact of the potential use of the technology by the investor. Third, a key alleged threat relates to the possibility of infiltration, surveillance or sabotage associated to the insertion of certain capabilities through FDI. This is a particularly strong concern regarding investments originating from state-owned-enterprises, given the influence of foreign governments' strategic objectives, beyond purely commercial motivations.

While regulating the entry of FDI worldwide is not a new phenomenon, there is a clear trend in recent years towards expanding the scope of existing mechanisms or creating new legal instruments, especially among top recipients of Chinese FDI, such as the U.S., Australia and the UK. This trend has intensified as China rises to leadership in high-tech sectors in telecommunications, leading the development of paradigm-shifting technologies such as 5G. As such, restrictions on the entry of Chinese FDI on national security grounds have become intertwined with geopolitical motivations, especially in the context of China-U.S. bilateral trade and technological dispute.

Accordingly, the U.S.' measures represent the most glaring example of increased scrutiny on Chinese FDI: In 2018, the U.S. enacted FIRRMA the Foreign Investment Risk Review Modernization Act - expanding the authority of the Committee on Foreign Investment of the U.S. (CFIUS) to review and potentially restrict any foreign investment, even those that do not result in a controlling interest. More recently, new regulations were 
adopted narrowing designations of "critical infrastructure", and "critical technologies" targeted by CFIUS, which include specific defense articles, nuclear equipment and "emerging and foundational technologies" (Chorzempa 2019).

In a similar fashion, the United Kingdom is currently reviewing its Enterprise Act in order to strengthen powers to scrutinize investments in assets raising national security concerns - having already amended thresholds to further intervene in three strategic areas: computing hardware, quantum technology and military/dual-use technology (United Kingdom 2018; Harrington 2019). While it is argued that such measures are not directly aimed at Chinese investments, the review process was initiated in the aftermath of investments from China General Nuclear (CGN) and China National Nuclear Corporation (CNNC) in the construction of UK`s Hinkley Point C Nuclear Power plant, in 2015.

Similarly, Australia has undergone a major controversy following the leasing of Port of Darwin - located nearby a military base used by U.S. marines - to Chinese Shandong Landbridge Group, also in $2015^{6}$. Since then, State Grid's attempts to acquire shares of energy distributor Ausgrid were blocked by the Australian Foreign Investment Review Board (FIRB). With advisory functions, FIRB screens investments on a case-by-case basis, and has publicly indicated an increased focus on acquisitions of data-rich entities and critical infrastructure ${ }^{7}$, particularly related to electricity, gas and water assets (FIRB 2019). Furthermore, Australia has enacted legislation strengthening screening mechanisms specifically for investments

\footnotetext{
${ }^{5}$ The U.S. government officially defines critical infrastructure as "systems and assets, whether physical or virtual, so vital to the United States that the incapacity or destruction of such systems or assets would have a debilitating impact on national security" (Department of the Treasury 2019).

${ }^{6}$ It is noteworthy that the Australian Department of Defense and security agencies had previously screened the Port of Darwin investment and concluded that it did not pose any relevant security risks, including from the point of view of espionage.

${ }^{7}$ The Australian government officially defines critical infrastructure as "those physical facilities, supply chains, information technologies and communication networks which, if destroyed, degraded or rendered unavailable for an extended period, would significantly impact the social or economic wellbeing of the nation or affect Australia's ability to conduct national defense and ensure national security" (Department of Home Affairs 2018).
} 
originating from state-owned-enterprises, subject to additional scrutiny and prior approval by the federal administration (Esplugues 2018).

While Australia and the UK offer clear examples of restrictions adopted largely in response to concerns related to critical infrastructure control (Esplugues's first potential threat), the U.S' measures tend to focus on the transfer of sensitive technologies (second potential threat) - meanwhile, risks of surveillance and sabotage, the third potential threat, are transversal and applicable to all three cases.

It is still unclear, though, the extent to which these restrictive measures respond to genuine risks or implausible worries, driven by protectionist or geopolitical motivations. According to Esplugues (2018), such threats are often exploited as excuses to adopt protectionist measures and restrict technology transfer. In a similar vein, Parker (2017) argues in favor of more realistic assessments and less politically motivated restrictions. The blurring between risk assessment and geopolitical interests has intensified in the context of the U.S' China trade war, as the U.S has explicitly alerted and compelled allies to restrict the acquisition of sensitive technologies by Chinese companies including Huawei and ZTE. Additionally, a common characteristic of most cases analyzed is the adoption of measures based on vague thresholds and broad definitions of national security risks particularly exemplified by the U.S' unspecified "emerging and foundation technologies" - allowing space for restrictions motivated by reasons other than safeguarding national security.

In the absence of multilateral understandings on foreign direct investment, restrictions have been adopted in a case-by-case basis, with individual national decisions gradually circumscribing the scope of Chinese global economic presence (Caramuru et al. 2019). Although investments restrictions on national security grounds have been more commonly observed in developed countries, pressures have also reached the developing world - including Latin America and Brazil. 


\section{Implications for Brazil}

In the Brazilian case, concerns about Chinese control over critical infrastructure $^{8}$ gained momentum in 2018. Through a number of controversial declarations - including that China would be "buying Brazil" - then candidate Jair Bolsonaro voiced concerns towards Chinese alleged "excessive" control of critical infrastructure, especially in energy transmission and generation sectors (Veiga \& Rios 2019). As a result, the period of uncertainty and mistrust represented a key factor underlying the substantial downfall in Chinese confirmed investments in Brazil between 2017 and 2018, falling from US\$ 8,8 billion to US\$ 3 billion (Cariello $2019 b$ ). Even though anti-China rhetoric has downscaled to a more moderate and pragmatic tone since then (Lapper 2019) - solidified by a series of high-level meetings carried throughout 2019 - the possibility of strengthening screening mechanisms and restricting Chinese investments in certain sectors cannot be completely ruled out.

Restrictions on Chinese investments, in Brazil, date back to 2010, when a legal opinion from the Attorney-General of the Union restricted acquisitions of land by companies controlled by foreigners ${ }^{9}$ (Hage et al. 2012). This decision prevented Chinese company Chongqin Grain Group (CGG) from acquiring large amounts of land aimed at cultivating soybeans, China's main import from Brazil (Escher et al. 2018). In that occasion, even though restrictions were largely motivated by Chinese planned investments, it is noteworthy that China was not among the main investors in rural land in Brazil at that time - ranking behind the U.S., the EU, Japan and Argentina, for instance (Escher et al. 2018).

\footnotetext{
8 The Brazilian government's official definition for "critical infrastructure" stems from a decree issued in November 2018, in which critical infrastructure are broadly defined as "installations, services and goods that, if interrupted or destroyed, will provoke grave social, economic, political or international impact and threaten national security" (Paiva, 2016). Furthermore, priority critical infrastructure areas include: energy, finance, transport, sanitation and telecommunications.

${ }^{9}$ Currently, there are at least two bills under discussion on Congress aiming to further regulate the acquisition of land by foreigners in Brazil: PL 4.059/2012 and PL $2963 / 2019$.
} 
In 2018, the new wave of apprehension towards Chinese investments was mostly directed at the energy sector, particularly at State Grid's and China Three Gorges' increased presence in energy generation and transmission, as seen in previous sections. Notably, State Grid currently controls the operation of around 14,200km of transmission lines in Brazil with another $2,500 \mathrm{~km}$ under construction. As such, State Grid's operating lines account for around $10 \%$ of the total Brazilian energy grid (State Grid Brazil Holding 2019). However, interest from foreign companies in Brazilian energy assets is not exclusively Chinese: Even though State Grid was part of the winning bid for major power transmission lines in recent years, it is noteworthy that energy auctions in Brazil have attracted numerous foreign investors from different countries - it has been argued, thus, that targeting specifically Chinese companies is in the least unreasonable (Caramuru et al. 2019).

More recently, in the context of the U.S.-China trade and technological dispute, the focus of investment restrictions to Chinese investments globally has shifted to sensitive technologies and infrastructure underlying the expansion of $5 \mathrm{G}$ technology. Beyond simply improving the speed of internet connection, $5 \mathrm{G}$ is expected to revolutionize telecommunications and establish the conditions for paradigm-shifting resources including autonomous vehicles and remote medical procedures (Collins 2018). In this process, Chinese Huawei has been single-handedly leading the race for $5 \mathrm{G}$ development, concentrating a large number of patents. Given Huawei's uncertain ownership and governance structure (Balding \& Clarke 2019), however, some countries have emphasized the security threats associated to its capabilities, including risks of surveillance and sabotage.

In the Brazilian case, Huawei's presence in Brazil dates back to 1999, when the company entered the Brazilian market focusing on mobile carriers, which still account for $70 \%$ of Huawei's revenue in Brazil (Proença \& Kupfer 2018). As Brazil plans to set its auction for 5G networks in 2020, pressures have intensified by U.S. officials in order to restrict Huawei's participation - with potential implications for intelligence sharing with Brazil (Mello 2019). Nonetheless, Brazilian National Telecommunications Agency (Anatel) has already announced that restrictions are not expected to be imposed on Huawei's investments - as the company maintains close 
dialogue with local and federal authorities on the matter (Caramuru et al. 2019).

Differently from the U.S. and other Western economies, Brazil lacks an institutional mechanism or legal instrument aimed at screening and restricting investments under national security grounds. On the other hand, under grounds of fair competition, a counterpart can be found in the Administrative Council on Economic Defense (CADE) - a federal autarchy with competence to analyze and prevent mergers and acquisitions that threaten fair competition, preventing the formation of cartels.

In order to fill this gap, aligning Brazil to recent global trends and allegedly safeguarding national security, there have been expectations towards a strengthening of screening mechanisms for FDI in Brazil. However, the experience of other countries shows that the blurring between realistic risk assessment and geopolitically driven restrictions might, ultimately, jeopardize investments beneficial to recipient countries' development. Through vague thresholds and broad definitions of critical infrastructure and sensitive technologies, a door is left open for discrimination against foreign investment on grounds other than national security.

In Brazil, the overall context of fiscal restraint and low investment rates - especially in infrastructure - will tend to press for a more pragmatic stance towards foreign investments, even in sectors that might require further attention. Realistically, it is unlikely that legislation is enacted restricting or prohibiting foreign investment in strategic sectors, as observed in certain cases. A more likely scenario is to strengthen regulatory agencies' monitoring of investment operations, ensuring compliance with local legislation (Caramuru et al. 2019; Veiga \& Rios 2019).

It is true that past expectations that Chinese investment would generate qualified jobs through high-tech industrial projects have so far been largely frustrated (Veiga \& Rios 2019). It is also true that socio-environmental concerns surrounding mega-infrastructure projects, regardless of the source of investments, should be closely monitored and regulated by national institutions. Nonetheless, the contributions of Chinese investments to the development of key sectors in Brazil in the past decade - generating employment, promoting the use of efficient technologies and reducing the infrastructure gap - should outweigh any politically driven restrictions. 


\section{Concluding remarks}

Against the backdrop of Chinese global investment drive in the $21^{\text {st }}$ century, the late upsurge in Chinese investments in Brazil since 2010 has significantly transformed the nature of Brazil-China economic relations. Responding to China's long-term food and energy security strategies - but also seeking profitable markets - foreign direct investment from Chinese companies in Brazil has evolved through different phases and sectors, ranging from commodities' supply chains to financial services and, more recently, to energy generation and transmission, as well as infrastructure and logistics. As Chinese investors familiarize with Brazilian regulatory framework, there is a greater disposition to invest in greenfield projects riskier but more beneficial to growth and employment - even though, in terms of value, mergers and acquisition remain Chinese companies' preferred investment modality in Brazil.

The fast upsurge in Chinese global investments has raised concerns worldwide, particularly regarding Chinese acquisitions of critical infrastructure and sensitive technologies - especially by Chinese central state-owned-enterprises, subject to SASAC's guidelines. By allowing foreign control of essential services - in areas such as energy, finance, sanitation and telecommunications - investments in critical infrastructure allegedly pose national security risks. These concerns have translated into a growing trend, particularly among developed economies, towards a strengthening of screening mechanism for FDI - implicitly or explicitly directed at China. A common characteristic of most measures, however, is the adoption of vague thresholds and broad definitions of critical infrastructure, allowing space for restrictions motivated by reasons other than safeguarding national security. In the context of the U.S.-China trade war and technological rivalry, realistic risk assessment has been increasingly blurred with geopolitical interests and motivations - with pressures towards the adoption of restrictive measures among U.S. allies, including Brazil.

As anti-China rhetoric rose during 2018 elections in Brazil, Chinese FDI experienced significant downfall, amid uncertainty over the possible adoption of investment restrictions. However, the complementarity and interdependence between Brazilian and Chinese economies has resulted in 
a prompt de-escalation: Rather than enacting legislation restricting foreign investment in strategic sectors, a more likely scenario is the strengthening of regulatory agencies' monitoring of investment operations, ensuring compliance with local legislation. The overall context of fiscal restraint and low public investment rates - especially in infrastructure - will tend to press for a more pragmatic stance towards foreign investments in Brazil, regardless of its source.

\section{References}

Avendano, R., A. Melguizo and M. Sean. 2017. "Chinese FDI in Latin America". Atlantic Council - Adrienne Arsht Latin America Center. Available at: https://publications.atlanticcouncil.org/china-fdi-latinamerica/

Balding, C. and D. Clarke. 2019. "Who owns Huawei?" SSRN. Available at: https://papers.ssrn.com/sol3/papers.cfm?abstract_id=3372669

Mello, Patrícia C. 2019. "EUA podem rever parceria de inteligência se Brasil permitir 5G chinês, diz diplomata". Folha de São Paulo. 31 de agosto, 2019.

Caramuru, M, C. Lins and Guilherme Ferreira. 2019. "Brazil-China: The state of the relationship, Belt and Road and lessons for the future". CEBRI - Brazilian Center for International Relations.

Cariello, T. 2019a. "The Brazilian framework in a global perspective", Chinese Investments in Brazil (2018), Brazil-China Business Council _. 2019b. "O comércio Brasil-China e os investimentos chineses no Brasil”. In A China por sinólogos brasileiros: Visões sobre economia, cultura e sociedade, ed. Evandro Menezes; Janaína Silveira. Río de Janeiro: Batel.

CEBC. 2016. "Investimentos Chineses no Brasil (2014-2015)". BrazilChina Business Council.

. 2017. "Perspectivas para a China no setor energético". Conselho Empresarial Brasil-China. Available at: https://cebc.org.br/2017/12/18/18a-edicao-perspectivas-para-a-chinano-setor-energetico/ 
CEBRI. 2018. "Financing and Participation in Infrastructure". V China Analysis Group Meeting.

Chorzempa, M. 2019. "New CFIUS regulations: more powerful, transparent and complex". Peterson Institute for International Economics (PIIE). Available at: https://www.piie.com/blogs/trade-and-investment-policywatch/new-cfius-regulations-more-powerful-transparent-and-complex

Clark, A. and C. Lins. 2019. "Infrastructure in 2022", Position Papers: CEBRI - Brazilian Center for International Relations. 81-94. Available at:

http://midias.cebri.org/arquivo/Livreto_Position\%20Papers\%20Trilingu e_FINAL.pdf

Collins, M., A. Das, A. Ménard and D. Patel. 2018. "Are you ready for 5G?" McKinsey \& Company. Available at:

https://www.mckinsey.com/industries/technology-media-and-

telecommunications/our-insights/are-you-ready-for-5g

United Kingdom, Department for Business, Energy and Industrial Strategy. "National Security and Investment: A consultation on proposed legislative reforms". White Paper. London: APS, 2018. Available at: https://assets.publishing.service.gov.uk/government/uploads/system/upl oads/attachment_data/file/728310/20180723_-

National_security_and_investment_-

_final_version_for_printing____.pdf

Department of Home Affairs, Australian Government. 2018. Security of Critical Infrastructure Act: An act to create a framework for managing critical infrastructure, and for related purposes.

Department of the Treasury, U.S. Government. 2019. Provisions Pertaining to Certain Investments in the United States by Foreign Persons. September 17, 2019.

Escher, F., J. Wikilson and P. Pereira. 2018. "Causas e implicações dos investimentos chineses no agronegócio brasileiro". Direction of Chinese Global Investments: Implications for Brazil. 289-338, Available at: http://funag.gov.br/loja/download/CHINESE-GLOBALINVESTIMENT_FINAL.pdf

Foreign Investment Review Board (FIRB), Australian Government. 2019. Address by Mr David Irvine AO, FIRB Chair to the Australia-China Business Council. 19 August 2019. 
Frischtak, C, A. Soares and T. Conor. 2013. "Uma análise dos investimentos chineses no Brasil: 2007-2012”. CEBC-Conselho Empresarial BrasilChina. Available at:

https://www.cebc.org.br/sites/default/files/pesquisa_investimentos_chin eses_2007-2012_-_digital_1.pdf

Hage, F., M. Peixoto, J. E. Vieira Filho. 2012. "Aquisição de terras por estrangeiros no Brasil: uma avaliação jurídica e econômica". Texto para Discussão 1795. Instituto de Pesquisa Econômica Aplicada (IPEA). Rio de Janeiro.

Harms, P. and P. Méon. 2014. "Good and bad FDI: The growth effects of greenfield investment and mergers and acquisitions in developing countries," Working Papers CEB 14-021, ULB -- Universite Libre de Bruxelles.

Harrington, R. 2018. "Government upgrades national security investment powers". Department for Business, Energy and Industrial Strategy, United Kingdom. Available at:

https://www.gov.uk/government/news/government-upgrades-nationalsecurity-investment-powers

Jaguaribe, A. "Characteristic and Direction of China's Global Investment Drive. In: Jaguaribe, Anna (Org.). 2018. Direction of Chinese Global Investments: Implications for Brazil. Alexandre de Gusmão Foundation (FUNAG), Ministry of Foreign Affairs. CEBC - Conselho Empresarial Brasil-China. Brasília: FUNAG.

Kupfer, D. and F. Freitas da Rocha. 2018. "Direções do Investimento Chinês no Brasil 2010-2016: Estratégia nacional ou busca de oportunidades". In: Jaguaribe, Anna (Org.), Direction of Chinese Global Investments: Implications for Brazil. Alexandre de Gusmão Foundation (FUNAG), Ministry of Foreign Affairs. CEBC - Conselho Empresarial Brasil-China. Brasília: FUNAG

Lapper, R. 2019. "Bolsonaro tenía a China em la mira pero la realidade lo desafio", Americas Quarterly, Vol. X. Available at: https://www.americasquarterly.org/content/lapper-span-las-rupturasson-dificiles

Lins, C. and G. Ferreira. 2019. "Logistics infrastructure in the Southeast region: an analysis of possible pathways for a partnership between Brazil 
and China". CEBRI - Brazilian Center for International Relations \& Catavento.

Moran, T. 2013. "Foreign acquisitions and national security: What are genuine threats? What are implausible worries?" In Zdenek Drabek; Petros Mavroidis (Ed.), Regulation of foreign investment: challenges to international harmonization. Singapore World Scientific, World Studies in International Economics. New York: Columbia University.

Esplugues Mota, C. 2018. "A more targeted approach to foreign direct investment: the establishment of screening systems on national security grounds". Brazilian Journal of International Law. Vol 15. No 2.

Parker, A. and R. Manuel. 2017. "PRC Investment in Critical Infrastructure". China Matters \& PwC Australia. Available at: http://chinamatters.org.au/wp-content/uploads/2017/12/PRCInvestment-in-Critical-Infrastrucutre-Report-PwC-and-ChinaMatters.pdf.

Proença, A. and D. Kupfer. 2018. "Experiências Empresariais". In Jaguaribe A. (Org.), Direction of Chinese Global Investments: Implications for Brazil. Alexandre de Gusmão Foundation (FUNAG), Ministry of Foreign Affairs. CEBC - Conselho Empresarial Brasil-China. Brasília: FUNAG.

SEAIN - Secretariat of International Affairs. 2018. Newsletter on Chinese Investment in Brazil $-n^{o}$ 7. Ministry of Economy. Released Dec $21^{\text {st }}$, 2018.

State Grid Brazil Holding. 2019. "About". Available at: https://www.stategrid.com.br/pagina-inicial/sobre/. Accessed on November 11, 2019.

Motta Veiga, P. and Sandra Ríos. 2019. “China's FDI in Brazil: recent trends and policy debate". Policy Brief-Policy Center for the New South. PB-19/20.

Velde, D. 2006. "Foreign Direct Investment and Development: An historical perspective. Background Paper for 'World Economic and Social Survey for 2006"'. Overseas Development Institute (ODI).

Wachholz, L. 2019. "Novas regras para o investimento chinês no mundo e seus possíveis efeitos para o Brasil”. In Menezes, E.; J. Silveira, A China por sinólogos brasileiros: Visões sobre economia, cultura e sociedade. Rio de Janeiro: Batel. 